\section{In vitro Propagation of Lychnophora pinaster (Asteraceae): A Threatened Endemic Medicinal Plant}

\author{
Ana V. de Souza, José E.B.P. Pinto ${ }^{1}$, Suzan K.V. Bertolucci, \\ and Ricardo M. Corrêa \\ Departamento de Agricultura, Universidade Federal de Lavras, 37200-000, \\ Cx. Postal 3037, Lavras, MG, Brazil
}

Larissa C. do B. Costa

Departamento de Ciências Biológicas, Universidade Estadual de Santa Cruz, 45662-000, lhéus, BA, Brazil

William E. Dyer

Plant Sciences Department, Montana State University, Bozeman, MT 59717

Additional index words. arnica, acclimatization, organogenesis, rooting, seed germination, shoots

\begin{abstract}
Lychnophora pinaster, known as arnica, is a medicinal plant of the Cerrado ecosystem in Brazil. It is widely used in the form of alcoholic extract for its antiinflammatory and anesthetic and healing effects on sprains, bruises, and inflammation. Owing to the great difficulty of propagation, it is listed by the Instituto Brasileiro do Meio Ambiente e dos Recursos Naturais Renováveis in the category of plants vulnerable to extinction. Micropropagation offers a solution to this problem by allowing the preservation and expansion of germplasm. The objective of this research was to establish a protocol for in vitro propagation of arnica. The best medium for germination of arnica embryos and plantlet growth was a quarter strength semisolid Murashige and Skoog medium (MS/4) containing $0.75 \%$ (w/v) sucrose. For shoot induction, the best results were obtained on MS/4 with $2.76 \mu \mathrm{M}$ of benzylaminopurine. Maximum shoot elongation before rooting occurred in the presence of $8.67 \mu \mathrm{M}$ of gibberellic acid for $19 \mathrm{~d}$. Microshoots were successfully rooted in the presence of $10.7 \mu \mathrm{M}$ of naphthalene acetic acid for $15 \mathrm{~d}$. After rooted plantlets were acclimatized in a greenhouse for $20 \mathrm{~d}$, the survival rate was $100 \%$ when planted in a soil from the area of occurrence of the species, whereas $0 \%$ survived when planted in Plantmax.
\end{abstract}

Lychnophora pinaster Mart. (arnica; Asteraceae) is a native woody perennial species from Brazil endemic to the stony fields of the Brazilian Cerrado, a woodland savanna, where it grows as $0.4-$ to $2.4-\mathrm{m}$ tall bushes. Flowering occurs from August to October and fruit dispersion in the months of December, January, and February. The flowers are lavender to crimson with a length of 8 to $10 \mathrm{~mm}$ (Semir, 1991). Its use as a topical application as a tincture of the aromatic leaves and flowers is considerable, owing to the antiinflammatory, anesthetic, and healing effects on bruises, sprains, and insect bites. Vegetative propagation of arnica using cuttings is somewhat troublesome because rooting is difficult. Furthermore, sexual reproduction is difficult as a result of the low viability of achenes (typically $2 \%$ to $5 \%$ ). Both of these constraints encourage

Received for publication 23 May 2007. Accepted for publication 5 July 2007.

This study was supported by the "Conselho Nacional de Desenvolvimento Científico e Tecnológico" (CNPq and $\mathrm{CNPq} / \mathrm{PIBIC}$ ).

${ }^{1}$ To whom reprint requests should be addressed; e-mail jeduardo@ufla.br. overharvesting of wild plants, leading to an extractive exploitation that exposes the species to the threat of extinction.

The interest in in vitro propagation of medicinal plants is clearly on the rise, because they represent the most important sources of medicines and other pharmaceutical products. Methods of in vitro propagation offer highly effective tools for germplasm conservation and mass multiplication of tion (Murch et al., 2004; Pan et al., 2003).

Two strategies have been used for micropropagation of woody species: callus regeneration and bud multiplication. However, plant regeneration based on callus formation can have drawbacks in regard to the maintenance of desired genetic stability as a result of somaclonal variation (Jayasankar, 2000). In general, bud multiplication represents the most reliable method for vegetative propagation (Einset, 1991).

Bud multiplication has been successfully used for the medicinal species Pogostemon heyneanus (Hembrom et al., 2006), Lychnophora ericoides (Pereira et al., 2005), Decalepis hamiltonii (Giridhar et al., 2005), Clitoria ternatea (Rout, 2005), Rauvolfia tetraphylla (Faisal et al., 2005), Eclipta alba many plant species threatened with extinc-
(Baskaran and Jayabalan, 2005), Rudgea viburnoides (Bonilla, 2002), Tournefortia paniculata (Bertolucci et al., 2000), and Echinodorus sp (Pereira et al., 2000).

Because micropropagation facilitates the establishment of a large number of plantlets in a relatively short period, and because there have been no studies on $L$. pinaster propagation, an attempt was made to develop protocols for micropropagation using nodal segments as well as plantlet development in different media for greenhouse acclimatization and field establishment.

\section{Materials and Methods}

Achenes from field $L$. pinaster plants were cleaned under air-flow shrunken $(95 \%)$ and were separated from full $(5 \%)$ achenes by water flotation. Full achenes were agitated in $70 \%(\mathrm{v} / \mathrm{v})$ alcohol for $1 \mathrm{~min}$, shaken in $2.5 \% \mathrm{NaCl}$ for $20 \mathrm{~min}$, and rinsed six times in distilled, autoclaved water in a laminar flow hood.

Effect of culture medium on embryo germination. Embryos were aseptically removed and cultured in horizontal position directly into culture tubes $(25 \times 150 \mathrm{~mm})$ containing either full strength $(1 \times)$, halfstrength (MS/2), or quarter-strength (MS/4) Murashige and Skoog salts with sucrose (Murashige and Skoog, 1962) and woody plant medium (WPM) (Lloyd and McCown, 1980) covered with a plastic lid and sealed with polyethylene film. Semisolid media were solidified with $0.6 \%$ Bacto agar and the $\mathrm{pH}$ was adjusted to $5.7 \pm 0.1$ before autoclaving at $1 \mathrm{psi}$ and $127^{\circ} \mathrm{C}$ for $20 \mathrm{~min}$. The tubes were placed in a growth chamber at $26 \pm 1{ }^{\circ} \mathrm{C}$ with a photoperiod of $16 \mathrm{~h}$ and light intensity of 25 to $30 \mu \mathrm{mol} \cdot \mathrm{m}^{-2} \cdot \mathrm{s}^{-1}$ under coolwhite fluorescent lamps. The same medium and conditions was used for all experiments.

Each treatment contained 25 embryos in four replications in a completely randomized experimental design. The percentage of germinated embryos was determined $15 \mathrm{~d}$ after culture and shoot and root lengths were measured after $45 \mathrm{~d}$.

Effect of cytokinin on multiple shoot induction from nodal segments. After 4 weeks on MS/4 medium, roots were removed from in vitro germinated plantlets and one $1-\mathrm{cm}$ long nodal segment was cultured vertically into shoot induction medium in culture tubes $(25 \times 150 \mathrm{~mm})$, which was closed with a plastic lid and sealed with polyethylene film. Shoot induction medium was $\mathrm{MS} / 4$ containing $0.75 \%(\mathrm{w} / \mathrm{v})$ sucrose, $0.7 \%$ Bacto agar, and $0,1.11,2.22$, or $4.44 \mu \mathrm{M}$ 6-benzylaminopurine (BA) or $0,1.13,2.26$, or 4.52 $\mu \mathrm{M}$ thidiazuron (TDZ). After $45 \mathrm{~d}$, the number of shoots per nodal segment and shoot lengths were determined. Each treatment consisted of four tubes with five replications in a completely randomized experimental design.

Effect of length of exposure to gibberellic acid on shoot elongation. One-cm long shoots were cultured vertically in semisolid 
MS/4 medium containing $0.75 \% \quad(w / v)$ sucrose, $0.7 \%$ Bacto agar, and $8.67 \mu \mathrm{M}$ gibberellic acid $\left(\mathrm{GA}_{3}\right)$ in culture tubes. Shoots were held in $\mathrm{GA}_{3}$ medium for 5,10 , 15 , or $30 \mathrm{~d}$. Shoots in the 15 -d treatment were transferred to $\mathrm{MS} / 4$ medium without $\mathrm{GA}_{3}$ for 30 more days. Shoot lengths were evaluated $45 \mathrm{~d}$ after the start of the experiment. Each treatment had five replications with four tubes per replication.

Effect of length of exposure to auxin on rooting of shoots. One-centimeter long shoots were cultured vertically in semisolid $\mathrm{MS} / 4$ medium containing $0.75 \% \quad(\mathrm{w} / \mathrm{v})$ sucrose and 5.37 or $10.74 \mu \mathrm{M}$ naphthalene acetic acid (NAA) or 4.92 or $9.84 \mu \mathrm{M}$ indole3-butyric acid (IBA) in culture tubes as described previously. Shoots were maintained on the medium for $1,5,10,15$, or $30 \mathrm{~d}$. In other treatments, shoots were transferred after these periods to the same culture medium without auxin. Evaluation of shoot length and total root number were made $30 \mathrm{~d}$ after transfer to fresh medium. Experiments were set up in a completely randomized experimental design, where the treatments were arranged in a 4 (auxin treatments) $\times 5$ (times to maintain on the medium) factorial scheme with five replications and four tubes per replication.

Effect of substratum type on the acclimatization of plantlets. In vitro rooted plantlets were transplanted into $50-\mathrm{mL}$ plastic cups filled with Plantmax (São Paulo, Brazil) (vermiculite, organic matter, macroand micronutrients; Eucatex Mineral Ltda), mineral soil not sterilized was collected from an area supporting wild arnica ("native soil"), or Plantmax:native soil (1:1 by volume) and covered with plastic bags to maintain humidity for $7 \mathrm{~d}$. The native soil analyses were: $\mathrm{pH}$ 5.0, $\mathrm{P}$ and $\mathrm{K}\left(\mathrm{mg} \cdot \mathrm{dm}^{-3}\right)=3.1$ and $47 ; \mathrm{Ca}^{+2}$, $\mathrm{Mg}^{+2}, \mathrm{Al}^{+3}, \mathrm{H}+\mathrm{Al}, \mathrm{SB},(\mathrm{t})$, and $(\mathrm{T})$ $\left(\mathrm{cmol}_{\mathrm{c}} \cdot \mathrm{dm}^{-3}\right)=0.5,0.2,1.1,5.0,0.8,1.9$, and 5.8.; $\mathrm{V}$ and $\mathrm{M}(\%)=14.1$ and 57; P-rem $\left(\mathrm{mg} \cdot \mathrm{L}^{-1}\right)=18.8$; and $\mathrm{OM}(\%)=3.1$. After removal of the bags, the cups were placed in a greenhouse under $50 \%$ shade net for $45 \mathrm{~d}$. Survival of the plantlets was evaluated after $45 \mathrm{~d}$. The experiment was conducted in a completely randomized experimental design in the greenhouse with 10 replications per treatment.

Statistical analysis. The data were analyzed by analysis of variance using a completely randomized design and regression analysis using SigmaPlot (Systat, San Jose, CA) (Windows version 8,2002 ).

\section{Results and Discussion}

Effect of culture medium on embryo germination. Embryos began to germinate 4 to $6 \mathrm{~d}$ after initial culture. The semisolid MS/4 medium supported the best germination rate $(68 \%)$. Furthermore, the best shoot growth was observed on this medium (Fig. 1).

No differences were observed in germination and shoot growth between MS and WPM (data not shown) (Lloyd and McCown, 1980). Similarly, germination of Hagenia abyssinica seeds was similar in either MS or
WPM (Feyissa et al., 2005). For Derris urucu seeds, germination on $\mathrm{MS}, \mathrm{MS} / 2, \mathrm{MS} / 4$, $\mathrm{MS} / 8$, or $\mathrm{MS} / 16$ medium ranged from $70 \%$ to $85 \%$ but was not different among the various media (da Conceição, 2000).

Low achene germination is an obstacle in the conventional propagation of $L$. pinaster. This problem can be overcome by in vitro propagation because a large quantity of plantlets is supplied quickly.

Effect of cytokinin on multiple shoot induction from nodal. Explants derived from young plants were successfully established in medium with a low-growth regulator concentration. In general, BA was more effective for multiplication of aerial parts, whereas there were no statistical differences among the TDZ concentrations tested (data not shown). The highest numbers of shoot buds (4.6) were obtained with $2.76 \mu \mathrm{M}$ BA after $45 \mathrm{~d}$ of culture according to regression analysis (Fig. 2). Higher BA concentrations were less effective in inducing shoot production. This rate of shoot multiplication was observed until the sixth subculture with a mean of 4.6 buds per explant throughout (data not shown).

According to Wildi et al. (1998), the improved response at higher BA concentrations is as a result of a reduction in the quantity of free polyphenols. In treatments without cytokinin, there was no multiplication, but only regeneration of axillary buds.

In medium with $4.44 \mu \mathrm{M} \mathrm{BA}$, bud number and sizes were lower than in the other concentrations tested. The buds presented symptoms of hyperhydration (abnormal
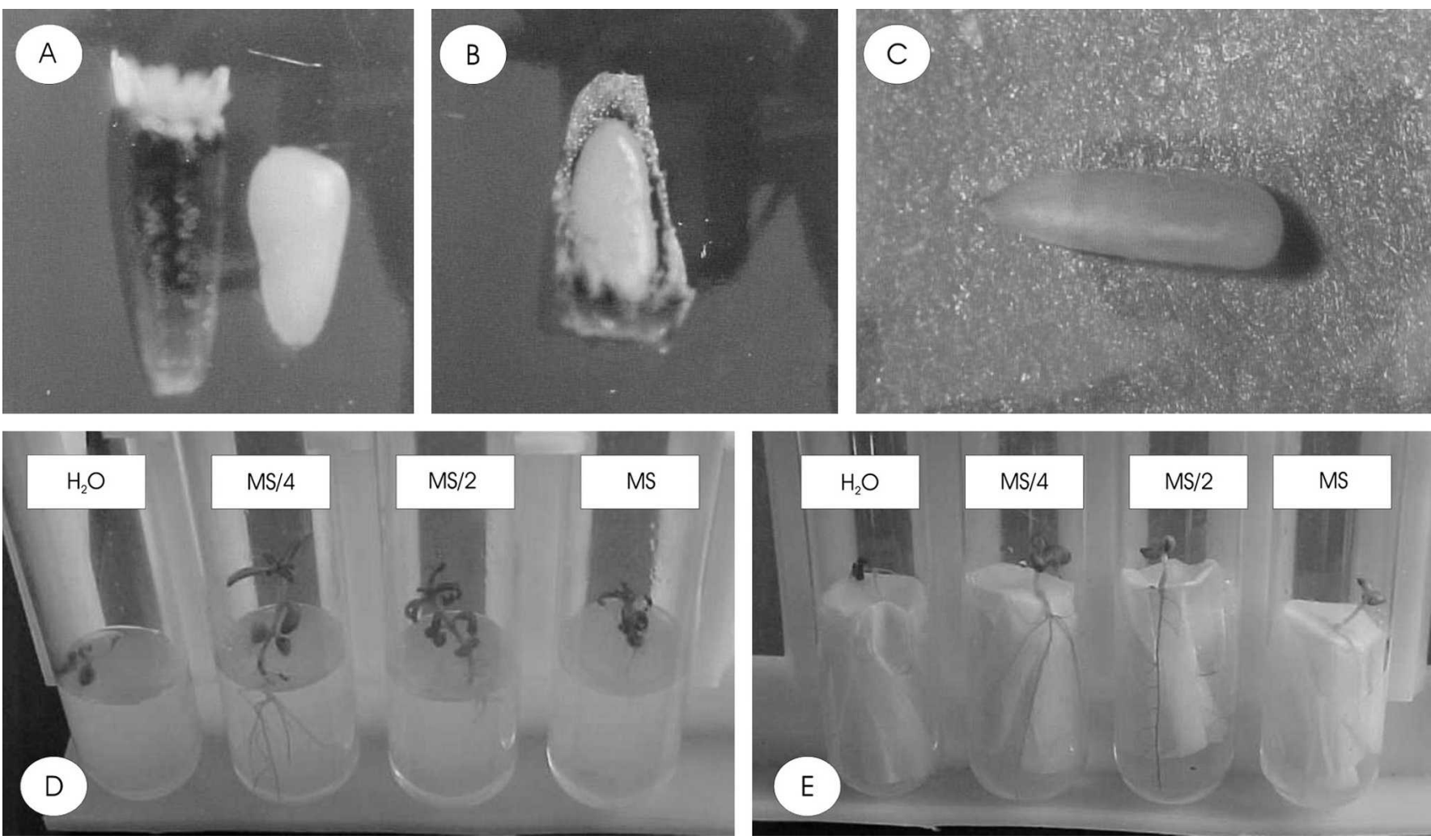

Fig. 1. (A and B) General aspect of achenes; (C) embryo; (D) embryo germination in semisolid medium: $\mathrm{H}_{2} \mathrm{O}$; MS/4; MS/2 and MS; (E) embryo germination in liquid medium: $\mathrm{H}_{2} \mathrm{O} ; \mathrm{MS} / 4 ; \mathrm{MS} / 2$ and $\mathrm{MS}$ (Lychnophora pinaster plantlet) after $45 \mathrm{~d}$. MS = Murashige and Skoog medium. 
leaves and swollen stems) as can happen with some species when higher cytokinin concentrations are used. In media with lower BA concentrations, no abnormal symptoms were observed. These symptoms were also observed in treatments containing TDZ (data not shown). Feyissa et al. (2005) reported the same symptoms when working on the multiplication of Hagenia abyssinica.

Different responses can be obtained depending on the study species, but George (1993) claimed that BA proved very effective for multiplication of aerial parts and induction of adventitious buds. Induction of axillary buds on Psiadia arguta (Asteraceae) was satisfactory in MS supplemented with $4.52 \mu \mathrm{M}$ TDZ (Kodja et al., 1998). A low BA concentration $(1.11 \mu \mathrm{M})$ also resulted in a higher number of buds (8.7) in nodal segments of $L$. ericoides, previously grown for $90 \mathrm{~d}$ in medium supplemented with $10.74 \mu \mathrm{M}$ NAA and $17.76 \mu \mathrm{M}$ BA (Pereira et al., 2005).

When the length of the buds was evaluated after $45 \mathrm{~d}$, the results differed between BA and TDZ as well. The length of the buds was significantly influenced by the concentration of BA (Fig. 3).

Effect of length of exposure to gibberellic acid on shoot elongation. Optimal shoot elongation was observed for shoots exposed to $\mathrm{GA}_{3}$ between 15 and $19 \mathrm{~d}$, because after $15 \mathrm{~d}$, the shoots presented $1.61 \mathrm{~cm}$ and grew to $1.65 \mathrm{~cm}$ when they were maintained for 19 d. Additional shoot elongation was not observed after exposure to $\mathrm{GA}_{3}$ for $30 \mathrm{~d}$. An inhibitory effect might have occurred incited by the longer exposure to gibberellin, maybe because of toxicity (Fig. 4).

Because arnica is a slow-growing species, in vitro as well as in vivo, the use of gibberellins for aerial elongation can be highly valuable in the development of rootable microshoots. Figueiredo et al. (2001) reported the need of $\mathrm{GA}_{3}$ for shoot elongation of Rollinia mucosa.

Effect of length of exposure to auxin on rooting of shoots. In vitro rooting of arnica microshoots was influenced by the auxin type. Different responses in shoot length and number of roots per shoots were obtained with the different concentrations as well as with the time the microshoots were exposed to the auxin. Lychnophora pinaster responded best to NAA. The genotypes differed in the rooting ability as observed for other species (Feyissa et al., 2005; Schoene and Yeager, 2005). Studies with Prunus fruticosa and $P$. tomentosa report the best rooting of the species when a combination of NAA and IBA was used (Pruski et al., 2005). Makunga et al. (2006) also reported the effect of the time of permanence of microshoots of Thapsia garganica in the IBA-supplemented medium. The elongated buds of Clitoria ternatea rooted within 7 to $8 \mathrm{~d}$ in halfstrength MS basal salts supplied with 1.34 $\mu$ M NAA (Rout, 2005).

Both auxin concentration and time of exposure of microshoots can influence rooting success. At excessive concentrations,

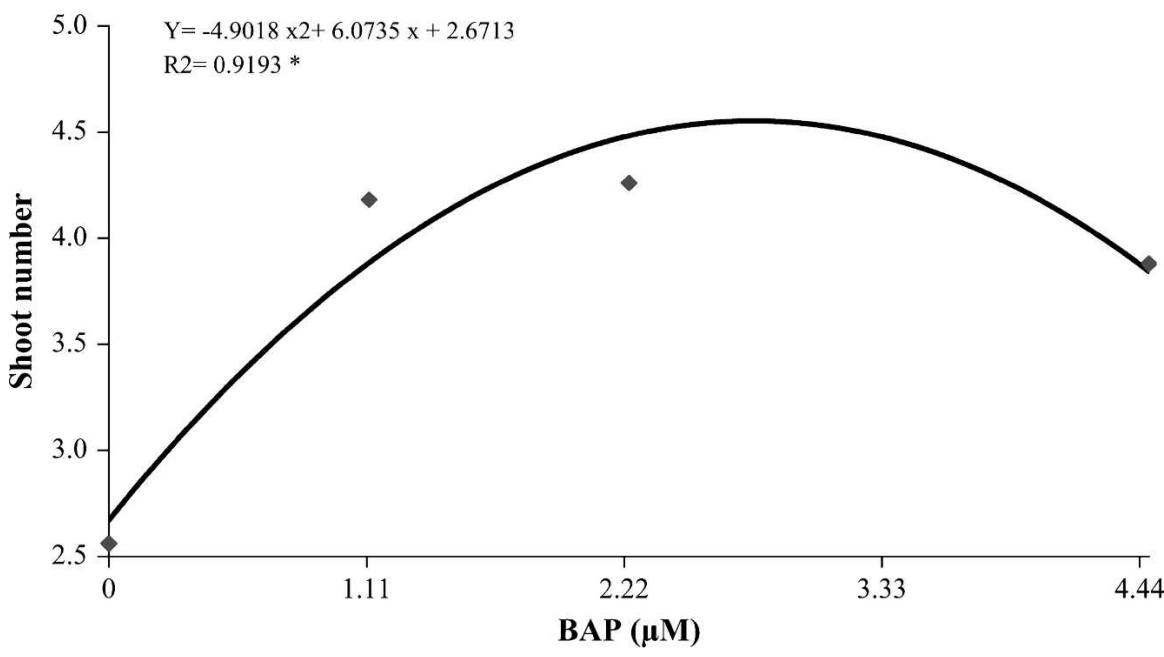

Fig. 2. Number of shoots of Lychnophora pinaster after $45 \mathrm{~d}$ cultured in Murashige and Skoog medium supplemented with 6 -benzylaminopurine. *Significant at $5 \%$ probability by the $\mathrm{F}$ test.

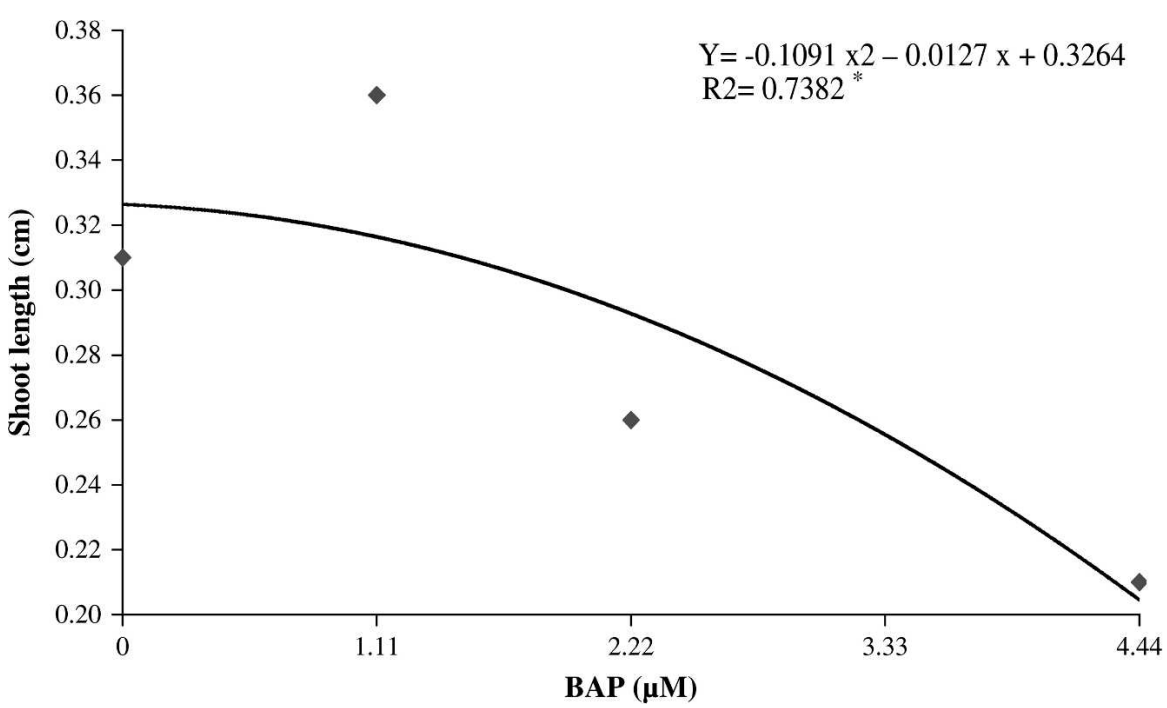

Fig. 3. Shoot length of Lychnophora pinaster after $45 \mathrm{~d}$ cultured in Murashige and Skoog medium supplemented with 6-benzylaminopurine.

toxicity can occur, leading to callus formation at the explant base and affecting the rhizogenesis and aerial shoot growth. However, other toxicity symptoms might only become manifested in the phase of root elongation, because there is an auxin-dependent stage in which rooting induction and initiation occurs, but if the plantlets remain in the presence of the auxin, root growth is inhibited. Still, some species can be maintained for long periods in the presence of auxin and no such toxicity is observed (Bonilla, 2002). This was not the case for $L$. pinaster, because the time of auxin exposure of the microshoots influenced the root initiation and shoot growth.

We observed that a longer exposure of arnica shoots to auxin resulted in growth inhibition, even at low auxin concentrations. When the microshoots were exposed for $\approx 15$ to $20 \mathrm{~d}$ and then transferred to an auxin-free medium, they grew normally. However, after $\approx 20 \mathrm{~d}$, inhibited growth was observed. The toxicity in this case may not be a result of the concentration used, but rather the time the shoots remained in the auxin. After $\approx 15 \mathrm{~d}$, the arnica microshoots had already attained sufficient shoot length for successful rooting; it is known that this is an essential factor in the development of a good root system as well.

The number of roots per arnica shoot was directly influenced by the auxin type and concentration used as well as by the time of exposure. An interaction was observed between the length of exposure and auxin concentration. It is known that rhizogenesis occurs during 1 to 3 weeks and can be divided into root induction, initiation, and elongation. In the first two phases, the roots can respond to and depend on auxin, whereas in the last phase, root growth can be inhibited by auxin. In the case of $L$. pinaster, the initial process of root induction appeared to occur during the 
first 3 weeks after transfer, as well as inhibition after the same length of time, for concentrations of NAA $(5.37$ and $10.74 \mu \mathrm{M})$ and IBA $(4.92 \mu \mathrm{M})$ (Fig. 5). The highest number of roots (9.79) was obtained in medium containing $10.74 \mu \mathrm{M}$ NAA with $16 \mathrm{~d}$ of exposure. This was the greatest number of roots observed, because in $5.37 \mu \mathrm{M}$ NAA, 3.68 roots were obtained after $17 \mathrm{~d}$ and 4.61 after $20 \mathrm{~d}$ when using $4.92 \mu \mathrm{M}$ IBA. Root numbers were lowest in medium containing $9.84 \mu \mathrm{M}$ IBA (Fig. 5).

Root production in the presence of 10.74 $\mu \mathrm{M}$ NAA increased from explants for $\approx 15 \mathrm{~d}$, after which it gradually decreased. This effect was weaker from microshoots in medium containing $4.92 \mu \mathrm{M}$ IBA or $5.37 \mu \mathrm{M}$ NAA, although root production decreased after $\approx 20 \mathrm{~d}$. There were no differences among regression curves of root production on these concentrations or $10.74 \mu \mathrm{M}$ NAA.

The influence of auxin on in vitro rooting is variable among various plant species, and in some cases, toxic effects from longterm exposure are not observed. In the case of Rudgea viburnoides, shoots remained in the presence of $2.46 \mu \mathrm{M}$ IBA for $60 \mathrm{~d}$ without negative effects (Bonilla, 2002). In that case, the lower concentration may explain the lack of toxicity. However, the time of exposure was $45 \mathrm{~d}$ longer than in $L$. pinaster, which apparently achieved optimal root production after only $15 \mathrm{~d}$ of auxin exposure. Echeverrigaray et al. (2000) also obtained good rooting responses of Chamomilla recutida at $0.5 \mu \mathrm{M}$ IBA. Higher IBA concentrations $(19.6 \mu \mathrm{M})$ were used in studies with Prunus armeniaca (Koubouris and Vasilakakis, 2006).

Effect of substratum type on acclimatization of plantlets. When plantlets of $L$. pinaster were transplanted to the commercial substratum Plantmax, the survival rate was $0 \%$. In contrast, there was $100 \%$ survival of the plantlets transplanted into mineral soil collected from an area supporting wild arnica ("native soil"). Approximately $80 \%$ plantlet survival was observed in a 1:1 mixture of native soil and Plantmax. We speculate that native soil may have contained mycorrhizae or other symbiotic microorganisms that allowed the transplants to survive.

The use of plastic bags to maintain the humidity in the first days of acclimatization was effective, because plantlets under this treatment grew well. Figure 6 shows the micropropagation of $L$. pinaster from the beginning with the multiple buds until the final acclimatization stage.

Some medicinal plant species apparently do not have special requirements for acclimatization and transplanting. When Bertolucci et al. (2000) used the commercial substratum Plantmax for plantlet acclimatization of the species Tournefortia cf paniculata, the survival rate was $100 \%$. The survival rate with Echninodorus sp plantlets was also $100 \%$ when transplanted into compost + red latosol (2:1) (Pereira et al., 2000).

In conclusion, micropropagation of L. pinaster was successful under a relatively

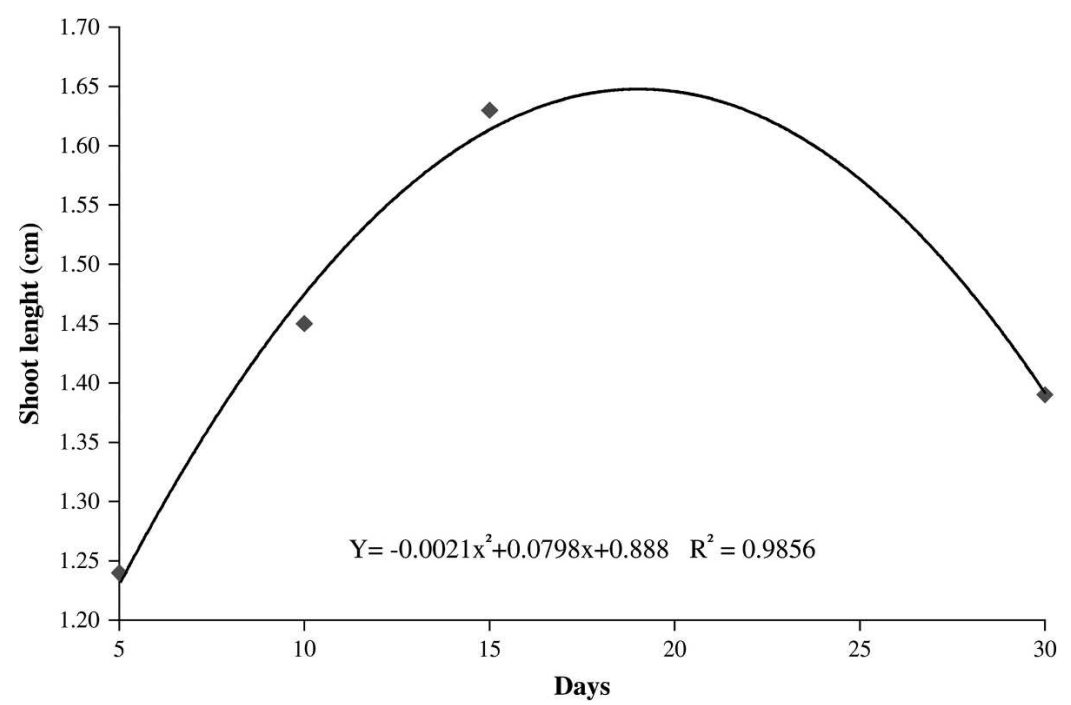

Fig. 4. Shoot length of Lychnophora pinaster in time function in Murashige and Skoog medium supplemented with $8.67 \mu \mathrm{m}$ gibberellic acid. *Significant at $5 \%$ probability by the $\mathrm{F}$ test.

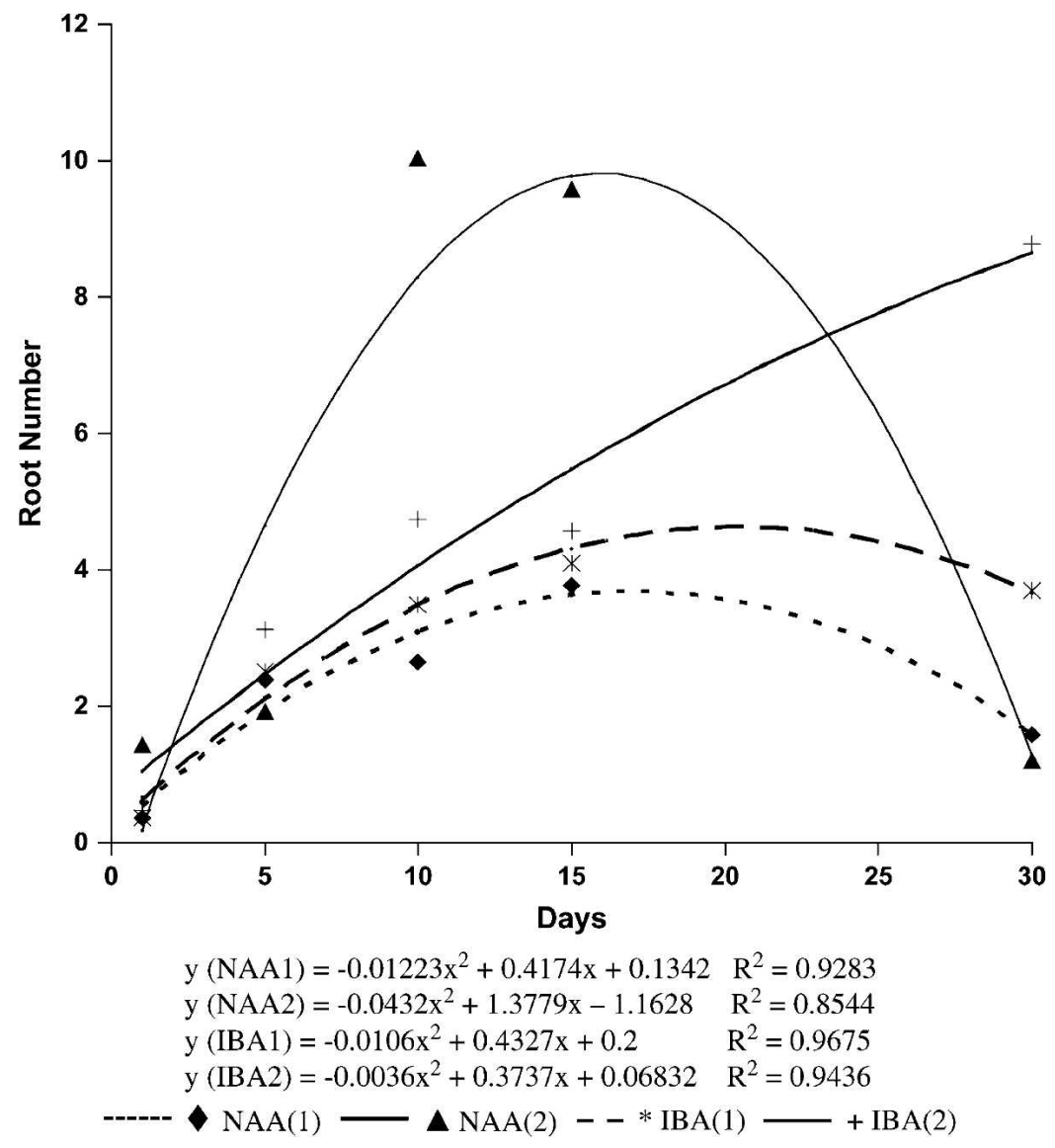

Fig. 5. Number of roots of Lychnophora pinaster plantlets related to time in Murashige and Skoog medium supplemented with $\alpha$-naphthalene acetic acid (5.37 or $10.74 \mu \mathrm{M}$ ) or indole-3-butyric acid (4.92 or $9.84 \mu \mathrm{M}) .{ }^{*}$ Significant at $5 \%$ probability by the $\mathrm{F}$ test.

simple tissue culture regime. MS/4 medium performed best of the recipes tested for in vitro cultivation of this species. In vitro multiplication of arnica was performed using low concentrations of BA to induce multiple buds. For rooting in vitro, good results were obtained with shoots exposed to $10.74 \mu \mathrm{M}$ NAA for 15 to $20 \mathrm{~d}$ and transferred to culture medium without a growth regulator. Fieldready $L$. pinaster plants were obtained by transplanting into soil collected from wild arnica areas. 

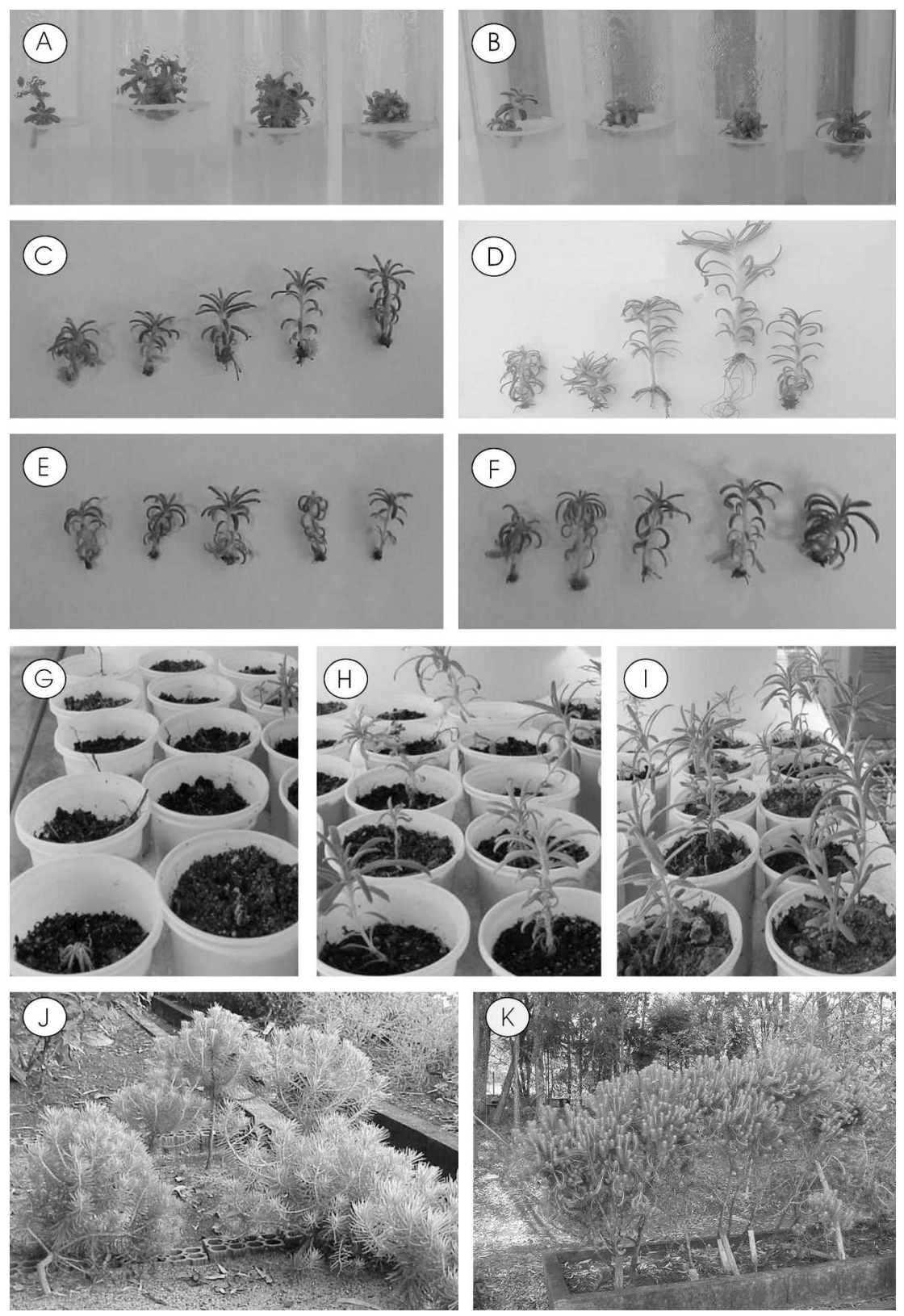

Fig. 6. Micropropagation of arnica: (A) shoot regeneration in 6-benzylaminopurine 0, 1.11, 2.22, and $4.44 \mu \mathrm{M}$ (left to right); (B) N-phenyl-N'-1,2,3-thiadiazol-5-yl urea 0, 1.13, 2.26, and 4.52 $\mu \mathrm{M}$ (left to right) after $45 \mathrm{~d}$; (C) shoot rooting in $1,5,10,15$, and $30 \mathrm{~d}$ in $5.37 \mu \mathrm{M} \alpha$-naphthalene acetic acid (left to right); (D) $10.74 \mu \mathrm{M} \alpha$-naphthalene acetic acid (left to right); (E) $4.92 \mu \mathrm{M}$ indole-3-butyric acid (left to right); (F) $9.84 \mu \mathrm{M}$ indole-3-butyric acid (left to right); (G) plantlet acclimatization in Plantmax substrate; $(\mathbf{H})$ Plantmax + soil from the occurrence area of the species; (I) in soil from the occurrence area of the species after only $52 \mathrm{~d}$; (J) plants after 12 months; and (K) plants after 36 months.

\section{Literature Cited}

Baskaran, P. and N. Jayabalan. 2005. An efficient micropropagation system for Eclipta alba-A valuable medicinal herb. In Vitro Cell. Dev. Biol. Plant 41:532-539.

Bertolucci, S.K.V., J.E.B.P. Pinto, M.G. Cardoso, M.L. Gavilanes, E.J.A. Santiago, and O.A. Lameira. 2000. Micropropagação de Tournefortia paniculata Cham. Braz. J. Med. Plants. 3:43-49.

Bonilla, M.G.O. 2002. Propagação in vitro, indução, curva de crescimento de calos e abordagem fitoquímica em Rudgea viburnoides (Cham.) Benth. Universidade Federal de Lavras, Lavras, PhD Diss.

da Conceição, H.E.O. 2000. Cultivo in vitro, nutrição mineral e quantificação de rotenóides em timbós (Derris sp.), Universidade Federal de Lavras, Lavras, PhD Diss.

Echeverrigaray, S., F. Fracaro, L.B. Andrade, S. Biasio, and L. Atti-Serafini. 2000. In vitro regeneration from leaf explants of Roman Chamomile. Plant Cell Tissue Organ Cult. 1:1-4.

Einset, J.W. 1991. Woody plant micropropagation with cytokinins, p. 190-201. In: Y.P.S. Bajaj (ed.). High-tech and micropropagation 1 . Springer-Verlag, Berlin.

Faisal, M., N. Ahmad, and A. Mohammad. 2005. Aerial part multiplication in Rauvolfia tetraphylla L. using thidiazuron. Plant Cell Tissue Organ Cult. 80:187-190.

Feyissa, T., M. Welander, and L. Negash. 2005. Micropropagation of Hagenia abyssinica: A multipurpose tree. Plant Cell Tissue Organ Cult. 80:119-127.
Figueiredo, S.F.L., N. Albarello, and V.R.C. Viana 2001. Micropropagation of Rollinia mucosa (Jacq.) Baill. In Vitro Cell. Dev. Biol. Plant 37:471-475.

George, E.F. 1993. Plant propagation by tissue culture. Part 1. The technology. Exegetics Ltd., Edington, UK.

Giridhar, P., H.B. Gururaj, and G.A. Ravishankar. 2005. In vitro aerial part multiplication through aerial part tip cultures of Decalepis hamiltonii Wight \& Arn., a threatened plant endemic to southern India. In Vitro Cell. Dev. Biol. Plant 41:77-80.

Hembrom, M.E., K.P. Martin, S.K. Patchathundikandi, and J. Madassery. 2006. Rapid in vitro production of true-to-type plants of Pogostemon heyneanus through dedifferentiated axillary buds. In Vitro Cell. Dev. Biol. Plant 42:283-286.

Jayasankar, S. 2000. Variation in tissue culture, p. 387-395. In: N.T. Robert and J.G. Dennis (eds.). Plant tissue culture concepts and laboratory exercises. New York Press, New York.

Kodja, H., J. Goviden-Soulange, A. Gurib-Fakim, I. Robene-Soustrade, L. Humeal, and J. Figier. 1998. Micropropagation of Psidia arguta through cotyledonary axillary bud culture. Plant Growth Regulat. 25:75-80.

Koubouris, G. and M. Vasilakakis. 2006. Improvement of in vitro propagation of apricot cultivar 'Bebecou'. Plant Cell Tissue Organ Cult 85:173-180.

Lloyd, G. and B. McCown. 1980. Commerciallyfeasible micropropagation of mountain laurel, Kalmia latifolia by use of shoot-tip culture. Proc. Intl. Plant Prop. Soc. 30:421-427.

Makunga, N.P., A.K. Jager, and J.V. Staden. 2006. Improved in vitro rooting and hyperhydricity in regenerating tissues of Thapsia garganica $\mathrm{L}$. Plant Cell Tissue Organ Cult. 86:77-86.

Murashige, T. and F. Skoog. 1962. A revised medium for rapid growth and bioassays with tobacco tissue cultures. Physiol. Plant. 15:473-497.

Murch, S., S.E. Peiris, C.Z. Liu, and P.K. Saxena. 2004. In vitro conservation and propagation of medicinal plants. Biodiversity 5:19-24.

Pan, Z.G., C.Z. Liu, and P.K. Saxena. 2003. Efficient plant regeneration from protoplasts of Egyptian medicinal plants Artemisia judaica L. and Echinops spinosissimus Turra. Plant Sci. 165:681-687.

Pereira, A.M.S., B.W. Bertoni, V.S. Fonseca, M.F.C. Amarante, N.P. Lopes, M.E. Paron, and S.C. França. 2005. Micropropagação e conservação de Lychnophora ericoides Mart.: Uma espécie medicinal do cerrado brasileiro. Revista Fitos. 1:69-73.

Pereira, F.D., J.E.B.P. Pinto, M.G. Cardoso, and O.A. Lameira. 2000. Propagação in vitro de chapéu de couro (Echinodorus cf saber Rataj): Uma planta medicinal. Ciência e Agrotecnologia 24:74-80.

Pruski, K., T. Astatkie, and J. Nowak. 2005. Tissue culture propagation of Mongolian cherry (Prunus fruticosa) and Nanking cherry (Prunus tomentosa). Plant Cell Tissue Organ Cult. 82:207-211.

Rout, G.R. 2005. Micropropagation of Clitoria ternatea Linn. (Fabaceae) - An important medicinal plant. In Vitro Cell. Dev. Biol. Plant 41:516-519.

Schoene, G. and T. Yeager. 2005. Micropropagation of sweet viburnum (Viburnum odoratissimum). Plant Cell Tissue Organ Cult. 83:271-277.

Semir, J. 1991. Revisão taxonômica de Lychnophora Mart. (Vernoniaceae: Compositae). Universidade de Campinas, Campinas, PhD Diss.

Wildi, E., K. Schaffner, and B. Buter. 1998. In vitro of Petasites hybridus (Asteraceae) from leaf and petiole explants and from inflorescence buds. Plant Cell Rep. 18:336-340. 